\title{
Drying Characteristics of Button Mushroom
}

\author{
Baddam Harshavardhini* and Pratibha Devi Sharma
}

Department of Processing and Food Engineering, College of Agricultural Engineering, Dr. RPCAU, PUSA, Samastipur, India

*Corresponding author

\section{Keywords}

Button Mushroom, drying air temperature, drying rate, rehydration, nutritional composition

Article Info

Accepted: 20 May 2021 Available Online: 10 June 2021

\section{A B S T R A C T}

Button mushrooms are highly perishable in nature because of its high moisture content about (85-90\%) hence starts deteriorating immediately within a day after harvest. So as to increase its shelf life three different samples of Button Mushroom Slices viz. untreated, blanched and optimized osmosed samples were taken for drying experiment at each level of drying air temperature $\left(50,60\right.$ and $\left.70^{\circ} \mathrm{C}\right)$. Drying of osmosed Button Mushroom slices at $70^{\circ} \mathrm{C}$ drying air temperature provided shortest drying time to produce best quality dried product as compared to blanched and untreated Button Mushroom samples. The drying time of osmosed sample was reduced to 480 minutes as compared to 600 and 660 minutes taken by blanched and untreated button mushroom samples. The osmotically dehydrated button mushroom samples showed best rehydration characteristics like Rehydration ratio of 4.98 and coefficient of rehydration of 0.493 and also produced the sample with good nutritional composition as compared to the other samples.

\section{Introduction}

Mushroom is a macroscopic fungus with distinctive fruiting body and lacks in chlorophyll, hence it requires a substrate for absorption of nutrients. The real fungus which is a microscopic fine thread like structure is used to grow on the substratum or below the surface of soil, it comes together in very compact form and spread out like an umbrella structure, when it is matured. Mushrooms have been found as time honoured food of many cultures all over the world (Chang and Buswell, 1996). They have not only been used for the consumption but also for medicinal purposes (Yang et al., 2001). Mushroom is an abundant supply of protein and it has been valued throughout the world for their flavour, texture as well as of their health benefits. Button mushrooms are highly perishable in 
nature because of its high moisture content about (85-90\%) hence starts deteriorating immediately within a day after harvest. Enzymatic action of polyphenol oxidase on phenolic substances causes deterioration of mushroom, which is identified by development of brown colour, and it shortens the shelf life (Dunkwal et al., 2007). Because of their high perishable nature, it needs to be processed to preserve for the off-season use.

Drying is an energy intensive process among the different methods of preservation. It reduces the water activity by decreasing moisture content. It is an easiest method to increase the shelf life of high moisture products (Shukla and Singh, 2007). But choosing a proper method of drying is important because of very sensitive nature of mushroom towards high temperature (Rezagah et al., 2010). The suitable method of drying should minimize the enzymatic and microbiological activities. Employing the osmotic dehydration as a pre-treatment of convective drying can improve the quality of final product. Hence, the hot air drying is to be done after osmotic dehydration of mushrooms (Shukla and Singh, 2007 and Dehkordi, 2010).

\section{Materials and Methods}

\section{Sample preparation}

The fresh and good quality button mushrooms were procured from the Mushroom Research Unit. Dr. RPCAU, Pusa. White button mushrooms of uniform size were washed thoroughly to remove adhering impurities and were graded properly to avoid variation in exposed surface area. The samples were vertically cut into uniform shape and size (approximately $5 \mathrm{~mm}$ thickness).

\section{Determination of moisture content}

The moisture content of the untreated, osmotically treated, blanched and osmo- air dried mushroom samples was determined by using the standard hot air oven method. Samples $(20 \mathrm{~g})$ were dried for $24 \mathrm{hr}$. in the hot air oven at $102 \pm 2{ }^{\circ} \mathrm{C}$ (AOAC, 1990).

Moisture content $\left(\mathrm{MC}_{\mathrm{W}}\right)$ was determined on wet basis as:

$M C_{w}=\frac{W_{m}}{W_{m}+W_{d}} \times 100$

Where,

$M C_{W}=$ Moisture content on wet basis, (percent)

$W_{d}=$ Bone dry weight, $(\mathrm{g})$

$W_{m}=$ Moisture evaporated, $(\mathrm{g})$

\section{Osmotic dehydration of button mushroom}

Osmotic dehydration of button mushroom slices was carried out prior to tray drying using salt solution as an osmotic agent. The experimental design was prepared by using independent and dependent variables as per the previous works of osmotic dehydration of different fruits and vegetables are given below. The solution to product ratio (SPR) was kept fixed at 10:1.

\section{Blanching of Button Mushroom}

Blanching of mushroom samples was done by using the method as described by Pacific Northwest (Extension Publication, Washington). The blanched mushroom samples were prepared by boiling the mushroom slices in water at $90^{\circ} \mathrm{C}$ for 2 minutes. After blanching, the samples were taken away from the boiling pan and left for cooling (15 to 20 minutes) and then remove excess water, by passing it through steel strainer. Finally, the mushroom slices were gently blotted with absorbent paper to remove the surface moisture. 


\section{Tray drying}

The drying operation was performed with the independent and dependent parameters/ variables to study the drying characteristics of different types of mushroom slices (osmosed, blanched and untreated).

The drying of mushroom slices was done by using laboratory tray drier. Untreated, blanched and selected osmosed mushroom slices were dried separately in tray drier with $200 \mathrm{~g}$ samples each.

The temperature of the dryer was set and fixed at three temperatures- $50^{\circ} \mathrm{C}, 60^{\circ} \mathrm{C}$ and $70^{\circ} \mathrm{C}$ for different drying runs which were replicated thrice. For a particular time interval the samples were taken out one by one and then final weight was measured using electronic balance (sensitivity: 0.01/0.1g)

All experiments were carried out at above mentioned three temperatures. Drying was carried out until the constant weight obtained.

$\left.W_{m}=\left\{1-\frac{w_{i}}{w_{t}}(1-\mathrm{M})\right\} \times 100\right\}$

Where,

$W_{m}=$ Moisture reduction, (percent, w.b).

$W_{i}=$ Initial sample weight. $\mathrm{g}$

$W_{t}=$ Sample weight at any time, $\mathrm{g}$.

$M=$ Initial moisture content in decimal, w.b.

Bone dry material $\left(\mathrm{W}_{\mathrm{bd}}\right)$ in the sample was determined by the following formula:

$\mathrm{W}_{\mathrm{bd}}=\frac{100}{100+\mathrm{MC}(\mathrm{db} \%)} \times \mathrm{W}_{\mathrm{i}}$

Drying rate (DR) was evaluated using the following formula:
$\mathrm{DR}=\frac{\text { Amount of water removal }}{\text { Time taken } \times \mathrm{W}_{\text {bd }}}$

Where,

Amount of Moisture Removal $=\mathrm{W}_{\mathrm{i}}-\mathrm{W}_{\mathrm{t}},(\mathrm{g})$

DR = Drying rate, $\frac{\left.{ }^{\frac{\text { Kgwater }}{\text { Kgdm.h }}}\right)}{{ }^{\prime}}$

$\mathrm{W}_{\mathrm{i}}=$ Initial weight of the sample $(\mathrm{g})$

$\mathrm{W}_{\mathrm{t}}=$ weight of the sample at any time, $(\mathrm{g})$

Time taken is equal to the interval of time between $\mathrm{W}_{\mathrm{i}}$ and $\mathrm{W}_{\mathrm{t}}$, in hour.

\section{Rehydration characteristics}

The rehydration quality of dehydrated mushroom samples was evaluated by rehydration test (Ranganna, 1986). It was done by placing the $10 \mathrm{~g}$ of samples with distilled water in glass beaker were heated in hot water bath at $60^{\circ} \mathrm{C}$ for $60 \mathrm{~min}$. The excess water was drained and surface moisture was removed by using filter paper then final weight of rehydrated samples was taken using electronic balance.

Rehydration ratio $\left(\mathrm{R}_{\mathrm{r}}\right)$ can be calculated from (Ranganna, 1999):

$\mathrm{R}_{\mathrm{r}}=\frac{C}{D}$

Where,

$\mathrm{C}=$ Weight of rehydrated samples after draining, $g$

$\mathrm{D}=$ weight of dehydrated samples taken for rehydration test, $\mathrm{g}$

The coefficient of Rehydration $\left(\mathrm{C}_{\mathrm{r}}\right)$, were computed using the equation (Ranganna, 1999): 
$\mathrm{C}_{\mathrm{r}}=\frac{\mathrm{Cx}(100-\mathrm{A})}{\left(\frac{\mathrm{D}-\mathrm{BD}}{100}\right) \times 100}$

m.c., $(\%$ w.b. $)=\left(\frac{\mathrm{c}-\left(\frac{\mathrm{D}-\mathrm{BD}}{100}\right)}{\mathrm{c}}\right) \times 100$

Where,

$\mathrm{A}=$ initial moisture content of the sample before dehydration, percent (w.b.)

$\mathrm{B}=$ moisture content of dehydrated sample, percent (w.b.)

$\mathrm{C}=$ weight of rehydrated samples after draining, $g$

$\mathrm{D}=$ weight of dehydrated samples taken for rehydration test, $\mathrm{g}$

Nutritional composition of button mushrooms

Approximate composition of the mushroom was determined by standard analytical methods. The total protein, fat, ascorbic acid, ash content and carbohydrates of the fresh and dehydrated mushroom samples were analyzed by standard procedures of Micro-Khjeldahl Method, Soxhlet method, Iodine titration method respectively.

\section{Results and Discussion}

\section{Drying characteristics}

From the Table 1 it has been revealed that there is an increase in reduction in moisture loss or weight reduction with increase in drying air temperature. A high temperature of drying air helps to bring down the time required for drying to bring the moisture content of all types' of mushroom samples to equilibrium.
It also reveals that the drying time required to dry untreated, blanched and osmo dehydrated mushroom samples at $50^{\circ} \mathrm{C}$ drying air temperature was 1020,840 and 660 minutes to reach moisture content of $9.21 \%, 9.08 \%$ and $8.79 \%$ respectively. It took 960,720 and 600 minutes to reduce the moisture content to $7.83,7.59$ and $7 \%$ for untreated, blanched and osmo treated button mushroom samples respectively at $60^{\circ} \mathrm{C}$. Whereas at $70^{\circ} \mathrm{C}$ it took only 720, 660, and 480 for untreated, blanched and osmo treated button mushroom samples to reach moisture content of $6.83 \%, 6.56 \%$ and $6.69 \%$ respectively.

From the Figures (1, 2 and 3 ) we have concluded that whole drying was carried out in falling rate period for the entire duration, it was due to the internal mass transfer occurred by the diffusion in all the samples.

Drying time reduces with increasing drying air temperature. According to kinetic theory the energy of water molecules increases as the temperature increases and it makes the water molecules to escape easier and faster. Higher temperature causes difference in vapour pressure between the surroundings and the product, which drives the moisture diffusion process (drying). (Prabhanjan et al.,1995)

Similar trend was quoted by Vergara et al., (1997) for osmotically dehydrated apple, Kar and Gupta (2003); Pokharkar (2002) for pine apple, Murumkar et al., (2007), and Jain et al., (2011) for papaya.

\section{Rehydration characteristics}

From the table 3 , it is clearly observed that the osmosed dehydrated mushroom sample dried at drying air temperature of $50^{\circ} \mathrm{C}$ had the highest rehydration ratio (4.98) as well as the highest coefficient of rehydration (0.443). 
Table.1 Variation in moisture content (\% w.b.) of mushroom samples during tray drying for different drying air temperatures

\begin{tabular}{|c|c|c|c|c|c|c|c|c|c|}
\hline \multirow{3}{*}{$\begin{array}{l}\text { Time } \\
\text { (min) }\end{array}$} & \multicolumn{9}{|c|}{ Moisture content (\% w.b.) } \\
\hline & \multicolumn{3}{|c|}{ Raw Samples } & \multicolumn{3}{|c|}{ Blanched Samples } & \multicolumn{3}{|c|}{ Osmosed Samples } \\
\hline & $50^{\circ} \mathrm{C}$ & $60^{\circ} \mathrm{C}$ & $7^{\circ} \mathrm{C}$ & $50^{\circ} \mathrm{C}$ & $60^{\circ} \mathrm{C}$ & $7^{\circ} \mathrm{C}$ & $50^{\circ} \mathrm{C}$ & $60^{\circ} \mathrm{C}$ & $7^{\circ} \mathrm{C}$ \\
\hline $\mathbf{0}$ & 92 & 92 & 92 & 91.6 & 91.54 & 91.5 & 75.17 & 75.3 & 75.65 \\
\hline 15 & 90.33 & 90.09 & 89.69 & 90.09 & 89.68 & 89.40 & 74.59 & 73.10 & 73.22 \\
\hline 30 & 88.46 & 88.24 & 86.85 & 88.38 & 87.82 & 86.84 & 73.48 & 70.99 & 70.96 \\
\hline 45 & 87.56 & 85.91 & 85.28 & 86.42 & 85.40 & 83.70 & 72.21 & 68.86 & 68.37 \\
\hline 60 & 86.04 & 83.92 & 82.82 & 84.77 & 82.51 & 80.62 & 70.97 & 66.51 & 65.24 \\
\hline 90 & 83.55 & 80.80 & 79.73 & 82.19 & 79.15 & 77.09 & 68.30 & 63.82 & 61.78 \\
\hline 120 & 80.90 & 77.43 & 76.02 & 76.48 & 75.52 & 72.96 & 65.87 & 60.24 & 56.96 \\
\hline 150 & 77.55 & 73.81 & 70.77 & 74.17 & 71.04 & 68.41 & 62.64 & 55.82 & 51.38 \\
\hline 180 & 72.96 & 70.08 & 64.60 & 71.47 & 65.31 & 63.16 & 58.72 & 50.48 & 41.40 \\
\hline 240 & 68.86 & 65.11 & 57.67 & 64.59 & 60.36 & 55.31 & 54.04 & 41.15 & 32.32 \\
\hline 300 & 62.25 & 60.11 & 48.49 & 58.54 & 52.42 & 46.44 & 48.35 & 35.21 & 17.97 \\
\hline 360 & 54.76 & 54.45 & 41.92 & 52.81 & 39.15 & 35.17 & 39.81 & 24.49 & 7.59 \\
\hline 420 & 47.51 & 50.03 & 34.87 & 45.57 & 25.82 & 26.22 & 29.21 & 11.99 & 6.69 \\
\hline 480 & 39.74 & 43.98 & 24.20 & 41.65 & 18.65 & 11.74 & 15.25 & 8.688 & 6.69 \\
\hline 540 & 34.29 & 32.13 & 15.88 & 30.66 & 11.03 & 8.022 & 9.620 & 7.4 & \\
\hline 600 & 30.02 & 22.93 & 8.734 & 22.94 & 8.260 & 6.56 & 8.79 & 7.4 & \\
\hline 660 & 18.07 & 17.08 & 6.83 & 15.09 & 7.59 & 6.56 & 8.79 & & \\
\hline 720 & 15.49 & 13.67 & 6.83 & 11.38 & 7.59 & & & & \\
\hline 780 & 11.60 & 10.84 & & 9.08 & & & & & \\
\hline 840 & 9.825 & 8.762 & & 9.08 & & & & & \\
\hline 900 & 9.52 & 7.83 & & & & & & & \\
\hline 960 & 9.21 & 7.83 & & & & & & & \\
\hline 1020 & 9.21 & & & & & & & & \\
\hline 1080 & & & & & & & & & \\
\hline
\end{tabular}


Table.2 Drying rate of mushroom samples during tray drying at different air temperatures

\begin{tabular}{|c|c|c|c|c|c|c|c|c|c|}
\hline \multirow{3}{*}{$\begin{array}{l}\text { Time } \\
(\mathrm{min})\end{array}$} & \multicolumn{9}{|c|}{ Drying rate $\left(\mathrm{kgw} \cdot(\mathrm{kg} \cdot \mathrm{dm})^{-1} \cdot \mathrm{h}^{-1}\right)$} \\
\hline & \multicolumn{3}{|c|}{$50^{\circ} \mathrm{C}$} & \multicolumn{3}{|c|}{$60^{\circ} \mathrm{C}$} & \multicolumn{3}{|c|}{$70^{\circ} \mathrm{C}$} \\
\hline & Untreated & Blanched & Osmosed & Untreated & Blanched & Osmosed & Untreated & Blanched & Osmosed \\
\hline $\mathbf{0}$ & & & & & & & & & \\
\hline 15 & 8.61 & 7.23 & 0.89 & 9.63 & 8.33 & 1.32 & 11.19 & 9.74 & 1.48 \\
\hline 30 & 7.66 & 6.58 & 0.76 & 7.98 & 7.14 & 1.20 & 9.77 & 8.50 & 1.32 \\
\hline 45 & 5.94 & 6.05 & 0.73 & 7.19 & 6.58 & 1.11 & 7.60 & 7.60 & 1.26 \\
\hline 60 & 5.33 & 5.33 & 0.69 & 6.27 & 6.07 & 1.06 & 6.67 & 6.66 & 1.22 \\
\hline 90 & 4.27 & 4.19 & 0.65 & 4.86 & 4.66 & 0.85 & 5.04 & 4.96 & 0.99 \\
\hline 120 & 3.63 & 3.82 & 0.59 & 4.03 & 3.85 & 0.76 & 4.16 & 4.05 & 0.89 \\
\hline 150 & 3.21 & 3.21 & 0.57 & 3.47 & 3.34 & 0.71 & 3.63 & 3.45 & 0.81 \\
\hline 180 & 2.93 & 2.79 & 0.56 & 3.05 & 2.97 & 0.67 & 3.22 & 3.02 & 0.80 \\
\hline 240 & 2.32 & 2.27 & 0.48 & 2.40 & 2.32 & 0.58 & 2.53 & 2.38 & 0.65 \\
\hline 300 & 1.97 & 1.89 & 0.43 & 1.99 & 1.94 & 0.50 & 2.11 & 1.98 & 0.57 \\
\hline 360 & 1.71 & 1.63 & 0.40 & 1.71 & 1.69 & 0.45 & 1.79 & 1.70 & 0.50 \\
\hline 420 & 1.51 & 1.43 & 0.38 & 1.49 & 1.49 & 0.41 & 1.56 & 1.48 & 0.43 \\
\hline 480 & 1.35 & 1.27 & 0.36 & 1.33 & 1.32 & 0.36 & 1.39 & 1.33 & 0.37 \\
\hline 540 & 1.21 & 1.16 & 0.32 & 1.22 & 1.18 & 0.32 & 1.25 & 1.18 & \\
\hline 600 & 1.10 & 1.06 & 0.29 & 1.12 & 1.07 & 0.29 & 1.140 & 1.07 & \\
\hline 660 & 1.02 & 0.97 & 0.26 & 1.02 & 0.97 & & 1.03 & 0.97 & \\
\hline 720 & 0.94 & 0.89 & & 0.94 & 0.89 & & 0.95 & & \\
\hline 780 & 0.87 & 0.83 & & 0.87 & & & & & \\
\hline 840 & 0.81 & 0.77 & & 0.81 & & & & & \\
\hline 900 & 0.75 & & & 0.76 & & & & & \\
\hline 960 & 0.71 & & & 0.71 & & & & & \\
\hline 1020 & 0.67 & & & & & & & & \\
\hline 1080 & & & & & & & & & \\
\hline
\end{tabular}

Table.3 Rehydration characteristics of rehydrated mushroom slices at different drying air temperatures.

\begin{tabular}{|c|c|c|c|c|}
\hline Sample Type & Temperature $\left.\mathbf{(}^{\mathbf{0}} \mathbf{C}\right)$ & $\begin{array}{c}\text { Moisture in } \\
\text { Rehydrated } \\
\text { Sample } \mathbf{( \% \mathbf { w . b } . )}\end{array}$ & Rehydration ratio & $\begin{array}{c}\text { Coefficient of } \\
\text { Rehydration }\end{array}$ \\
\hline Untreated & 50 & 86.93 & 3.24 & 0.302 \\
\hline Blanched & 50 & 87.13 & 3.87 & 0.378 \\
\hline Osmosed & 50 & 88.46 & $\mathbf{4 . 9 8}$ & $\mathbf{0 . 4 4 3}$ \\
\hline Untreated & 60 & 86.13 & 3.09 & 0.297 \\
\hline Blanched & 60 & 86.97 & 3.63 & 0.347 \\
\hline Osmosed & 60 & 87.88 & 4.63 & 0.423 \\
\hline Untreated & 70 & 85.83 & 2.97 & 0.254 \\
\hline Blanched & 70 & 86.26 & 3.54 & 0.326 \\
\hline Osmosed & 70 & 86.97 & 4.48 & 0.401 \\
\hline
\end{tabular}


Table.4 Proximate composition of dehydrated mushrooms

\begin{tabular}{|c|c|c|c|c|c|c|c|}
\hline Mushroom & \multicolumn{7}{|c|}{ Parameters (g/100g) } \\
\cline { 2 - 8 } & $\begin{array}{c}\text { Moisture } \\
\text { content } \\
(\mathbf{g})\end{array}$ & $\begin{array}{c}\text { Protein } \\
(\mathbf{g})\end{array}$ & $\begin{array}{c}\text { Fat } \\
(\mathbf{g})\end{array}$ & $\begin{array}{c}\text { Ascorbic } \\
\text { acid } \\
(\mathbf{g} / \mathbf{1 0 0})\end{array}$ & $\begin{array}{c}\text { Ash } \\
\text { content } \\
(\mathbf{g})\end{array}$ & $\begin{array}{c}\text { Fibre } \\
(\mathbf{g})\end{array}$ & $\begin{array}{c}\text { Carbohydrate } \\
(\mathbf{g})\end{array}$ \\
\hline $\begin{array}{c}\text { Fresh } \\
\text { Untreated }\end{array}$ & 71.7 & 2.1 & 0.33 & 0.1025 & 0.76 & 1.3 & 3.78 \\
\hline $\begin{array}{c}\text { dehydrated } \\
\text { Blanched } \\
\text { dehydrated }\end{array}$ & 7.9 & 25.4 & 2.0 & 0.0278 & 9.5 & 11.04 & 44.14 \\
\hline $\begin{array}{c}\text { Osmosed } \\
\text { dehydrated }\end{array}$ & 7.54 & 25.9 & 2.23 & 0.0193 & 10.02 & 10.87 & 43.26 \\
\hline
\end{tabular}

Values are average of three replications

Fig.1 Deviation of drying rate for different types of mushroom slices with average moisture content (\%,w.b.) at $50{ }^{\circ} \mathrm{C}$ dying air temperature

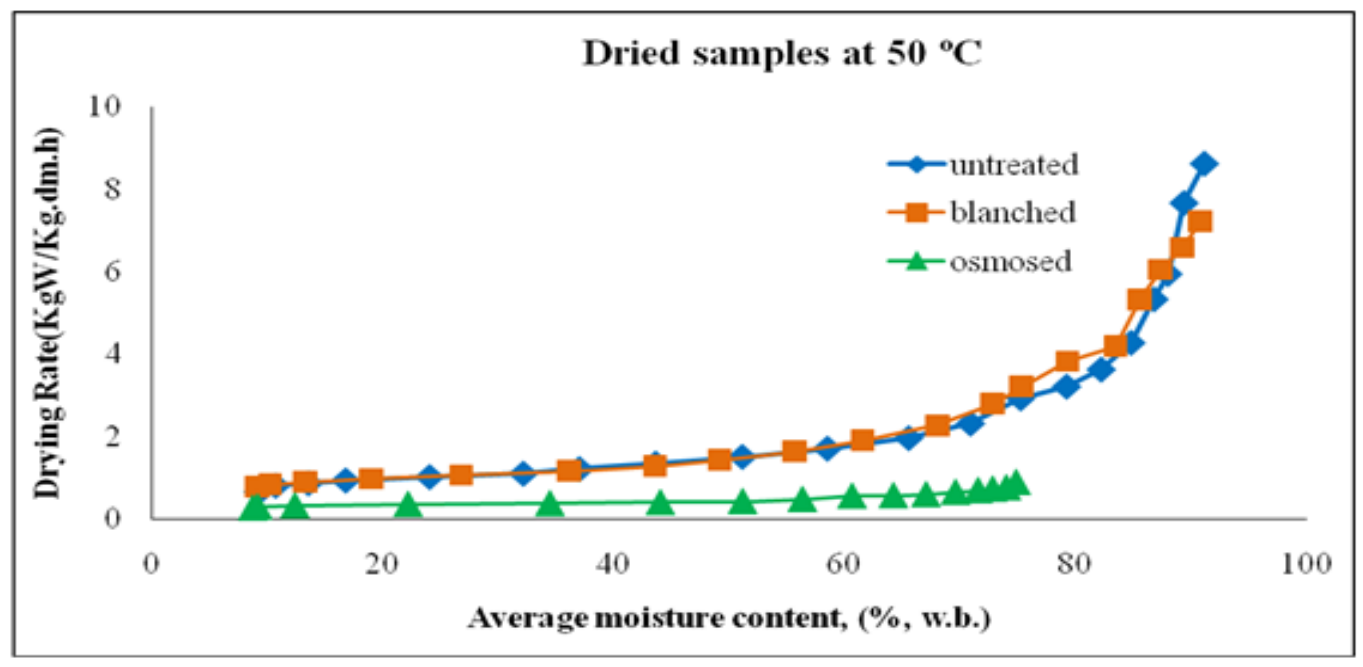

Fig.2 Deviation of drying rate for different types of mushroom slices with average moisture content (\%,w.b.) at $60^{\circ} \mathrm{C}$ drying air temperatures

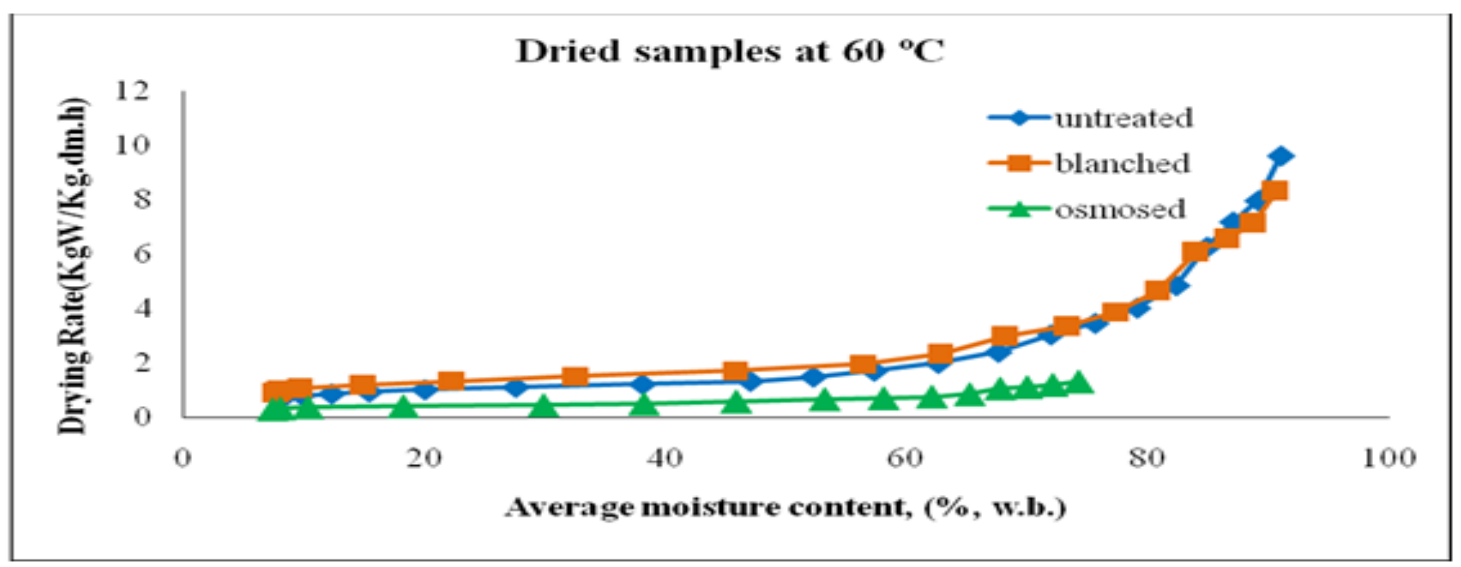


Fig.3 Deviation of drying rate for different types of mushroom slices with average moisture content (\%,w.b.) at $70^{\circ} \mathrm{C}$ drying air temperatures

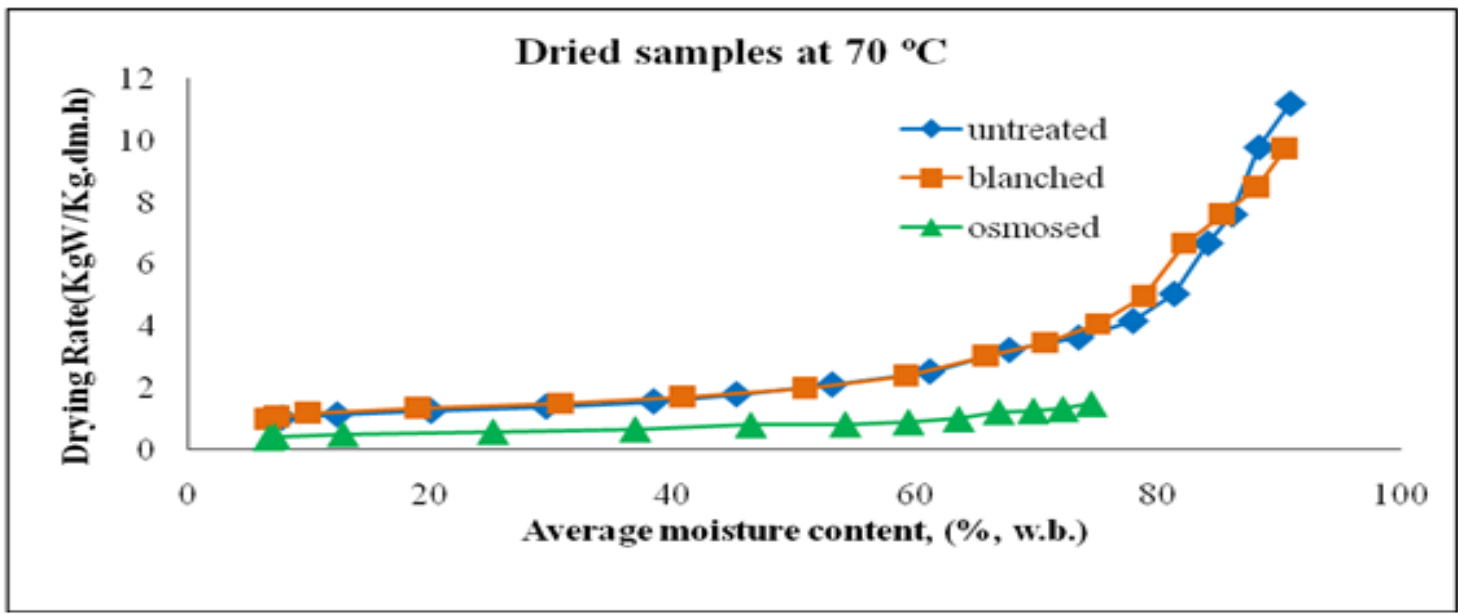

The rehydration ratio of osmo dehydrated mushroom is higher as compared to untreated samples at all drying temperatures. It may be noted that the sample having the higher rehydration ratio found to have better quality. Similar results were reported by (Kulshreshtha et al., 2009, Bhuvaneswari et al., (1999).

\section{Nutritional composition of button mushroom}

The proximate analysis of fresh button mushroom (A. bisporus) sample shown in table 4 , had $91.7 \%$ moisture, $2.1 \%$ crude protein, $1.3 \%$ of crude fibre, $0.76 \%$ ash, 3.78 $\%$ carbohydrates and $0.33 \%$ fat (w.b) similar range was obtained in other study (Mattila et al., 2002). According to present study there is an increase in protein content, fat, ash, fibre and carbohydrates in dried mushroom samples as compared to fresh sample. The decrease in the value of ascorbic acid was found in all the dried samples, ascorbic acid (vitamin C) is very sensitive and might get degraded at higher temperature. An increase of protein in dried samples is due to the dehydration of water that exists in between the proteins. The carbohydrates percentage increased with decrease in moistures content during the drying due to the concentration of nutrients
(Reid et al., 2017). A similar trend was observed by Longvah and Deosthale (1998). The increase in ash content in osmotically dried mushrooms is might be due to the presence of sodium in the solution, which might have diffused into the mushroom slices when the water drained out. This is due to the simultaneous process of water and solute diffusion in osmotic dehydration (Krokida et al., 2003 and Lerici et al., 1985). The tray drying of osmosed button mushroom at $70^{\circ} \mathrm{C}$ air temperature needed short drying time to make stable product with good quality dried product as compared to blanched and raw mushroom samples. The time needed to dry the osmotically treated mushroom was reduced to 480 minutes at $70^{\circ} \mathrm{C}$ whereas the blanched and untreated mushroom samples needed 600 and 660 minutes respectively.

The osmo dehydrated button mushrooms were found to have better rehydration characteristics as well as better nutritional composition as compared to other samples treated at all drying air temperature. The higher rehydration ratio $\left(\mathrm{R}_{\mathrm{r}}\right)$ and coefficient of rehydration $\left(\mathrm{C}_{\mathrm{r}}\right)$ of osmo dehydrated sample was found as $4.98 \%$ and 0.443 respectively at $50^{\circ} \mathrm{C}$ drying air temperature. 


\section{References}

Anonymous (1990). AOAC.: "Official Method of Analysis", 15 Edition. Association of Official Analytical Chemists. Washington D.C.

Bhuvaneswari, S., Sreenerayan, V. V., Kaillappan, R. and Parvathy, K. 1999. Osmotic dehydration of peas. Indian Food Packer, 40: 10-12.

Chang, ST. and Buswell, JA. 1996. Mushroom nutriceuticals. W. J. Micro.and Biotech., 12: 473-476.

Dehkordi, B. M., 2010. Optimization of the Process of Osmo-Convective Drying of Edible Button Mushrooms using Response Surface Methodology (RSM). World Academy of Science, Engineering and Technology,37, pp.1014-1018.

Dunkwal, V., Jood, S. and Singh, S. 2007. Physico-chemical properties and sensory evaluation of Pleurotussajorcaju powder as influenced by pre-treatments and drying methods. British Food J., 109(9): 749-759.

Jain, S. K., Verma, R. C., Murdia, L. K., Jain, H. K. and Sharma, G. P. 2011. Optimization of process parameters for osmotic dehydration of papaya cubes. Journal of Food Sci. Technology. 48(2): 211-217.

Kar A. and Gupta D. K. 2003, Studies on airdrying of osmosed button mushrooms. Journal of Food Science and Technology,40(1): 23-27.

Krokida M K, Karathanos V T, Maroulis Z B, Marinos-Kouris D., 2003. Drying Kinetics of some vegetables. Journal of Food Engineering.59,pp.391-403.

Kulshreshtha, M., Singh, A. and Vipul, D., 2009. Effect of drying conditions on mushroom quality. Journal of Engineering Science and technology, 4(1), pp. 90-98.
Lerici C R, Pinaavaia G, Dalla Rosa M, Bartolucci L., 1985. Osmotic dehydration of fruit: Influence of osmotic agents on drying behaviour and product quality. Journal of Food Science. 50(5):1217-1219.

Longvah, T., Deosthale, Y. G. (1998). Composition and nutritional studies on edible wild mushroom from northeast India. Food Chemistry, 63, 331-334.

Mattila, P., Salo-Väänänen, P., Könkö, K., Aro, H. and Jalava, T., 2002. Basic composition and amino acid contents of mushrooms cultivated in Finland. Journal of Agricultural and Food Chemistry, 50(22), pp.6419-6422

Murumkar, R. P, Jain, S. K., Pilaskar, P. S. and Verma, R. C. 2007. Osmo-fluid bed drying of white button mushroom. Bioved- An International Bi-annual Journal of Life Science, 18(1-2): 4752.

Pokharkar, S. M. and Prasad, S. 2002. Air drying behaviour of osmotically dehydrated pineapple. J. Food Sci. Technol, 39:384-387.

Prabhanjan, D. G., Ramaswamy, H. S. and. Raghavan, G. S. V. 1995. Microwaveassisted convective air drying of thin layer carrots. Journal of Food Engineering, 25:283-293.

Ranganna, S. (1986). Hand book of analysis and quality controller fruit and vegetable products. Tata McGraw Hill publication Co, New Delhi.

Reid, T., Munyanyi, M. and Mduluza, T., 2017. Effect of cooking and preservation on nutritional and phytochemical composition of the mushroom Amanita zambiana. Food science \& nutrition, 5(3), pp.538-544.

Rezagah, M. E., Kashaninejad, M., Mirzaei, H. and Khomeiri, M., 2010. Osmotic dehydration of button mushroom: Fickian diffusion in slab configuration. Latin American applied research, 
40(1), pp.23-26.

Shukla, B. D. and Singh, S. P. 2007. Osmoconvective drying of cauliflower, Mushroom and Greenpea. Journal of Food Engineering. 80: 741-747.

Vergara, F. and Welti, Amezaga, E., Barcenas, M. E. and Welti, J. 1997. Analysis of the drying processes of osmotically

dehydrated apple using the characteristic curve model. Drying Technology, 15:949-963.

Yang, J. H., Lin, H. C. and Mau, J. L. 2001. Non-volatile taste components of several commercial mushrooms. Food Chem., 72: 465471.

\section{How to cite this article:}

Baddam Harshavardhini and Pratibha Devi Sharma. 2021. Drying Characteristics of Button Mushroom. Int.J.Curr.Microbiol.App.Sci. 10(06): 503-512.

doi: https://doi.org/10.20546/ijcmas.2021.1006.054 